\title{
LOW COST WHEELCHAIR *
}

By R. G. Bosshard, Ing. EPF-L, M.I.B.M.E., M.I.E.E.E. ${ }^{1}$ and J. D. Yeo, A.O., D.P.R.M., F.R.A.C.S., F.A.C.R.M. ${ }^{2}$

${ }^{1}$ Biomedical Engineer, ${ }^{2}$ Director, Spinal Unit, Royal North Shore Hospital, St Leonards, Sydney, New South Wales 2065, Australia.

Summary. This wheelchair is a new concept in wheelchair design, made entirely of readily available plastic materials and rear bicycle wheels. The chair does not require a cushion, weights only $12 \mathrm{~kg}$ with $100 \mathrm{~mm}$ front castors or $13 \mathrm{~kg}$ with I $75 \mathrm{~mm}$ castors. It is easy to manoeuvre.

The design allows this wheelchair to be used as a conventional wheelchair and a shower/commode chair. Side arms and brakes can be attached if required. The necessary materials are relatively inexpensive and generally available in most countries.

Key words: Wheelchair design and cost; Mobility aid; Plastic material.

\section{Introduction}

IN the Royal North Shore Hospital of Sydney, Ioo spinal patients from neighbouring countries as well as from our own country, are treated each year. There is a pressing need to supply patients from the developing countries with a simple low-cost, 'do-it-yourself and repair-yourself' wheelchair for the return to their local community. A lightweight wheelchair has now been made available, built from standard off the shelf materials, which can be easily purchased in the local hardware suppliers.

\section{Detailed Desciption}

The wheelchair is constructed from three parts; the frame, the seat and the wheels. Figure I shows the chair without arm rests, although arm rests and brakes are optional.

\section{The frame}

The frame is made of standard plumbing polyvinylchloride (PVC) pressure fittings and pipes of $15 \mathrm{~mm}$ nominal diameter. An exploded view of the frame is shown in Fig. 2, and demonstrates the positioning of the PVC fittings. Dotted lines represent sections of the. $15 \mathrm{~mm}$ PVC piping.

The fittings and pipes are glued together with a methyl ethyl ketone based solvent cement. For ease and accuracy of assembly it is preferable to use jigs when positioning two fittings at set angles to one another. The whole chair can be assembled without jigs, although it is essential to use a protractor for accurate angles. Table I summarises the quantity of PVC plastic necessary for one frame.

* Read at the Annual Scientific Meeting of the International Medical Socieity of Paraplegia, Athens, Greece. October 1982. 


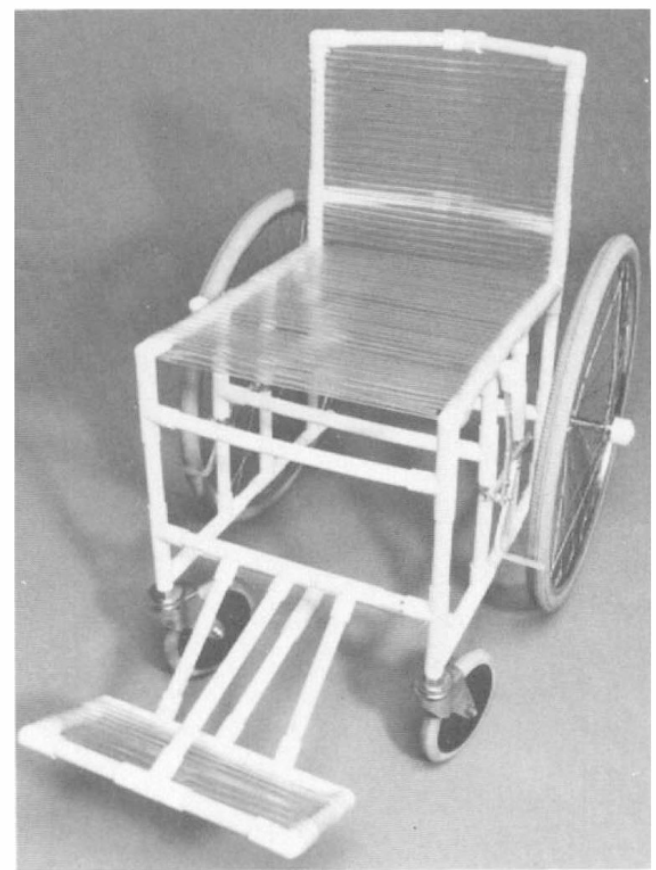

FIG. I

Plastic Wheelchair.

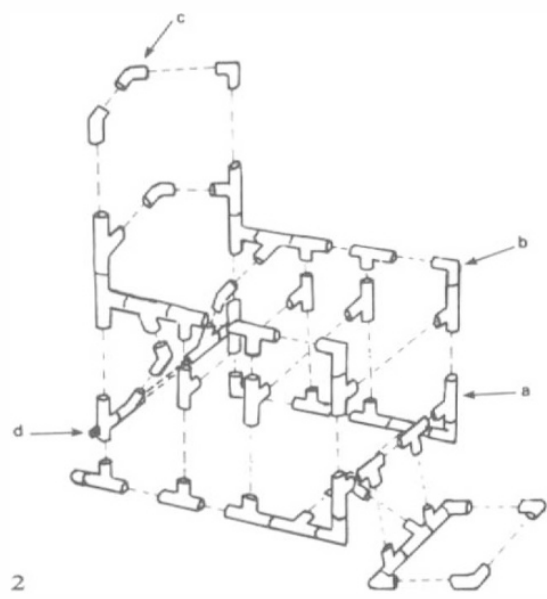

FIG. 2

Details of the frame (a) tee fitting; (b) $90^{\circ}$ elbow; (c) $45^{\circ}$ elbow; (d) horizontal axle.

Once the frame is assembled and glued it cannot be modified unless sections of pipe are cut and extended or shortened with straight connectors. The two $600 \mathrm{~mm}(24$ inch) bicycle wheels on each side of the frame are screwed into the aluminium alloy axle. This axle is of $16 \mathrm{~mm}$ diameter and $455 \mathrm{~mm}$ in length. Both ends of this axle are drilled to $30 \mathrm{~mm}$ in 
TABLE I

Amount of PVC plastic per chair

\begin{tabular}{|c|c|c|c|c|}
\hline \multicolumn{5}{|c|}{ Fitting } \\
\hline $\begin{array}{c}\text { Tees } \\
37\end{array}$ & $\begin{array}{c}\text { Elbows } \\
90^{\circ} \\
9\end{array}$ & $\begin{array}{c}\text { Elbows } \\
45^{\circ} \\
4\end{array}$ & $\begin{array}{l}\text { Caps } \\
\text { I } 5 \mathrm{~mm} \\
\text { I }\end{array}$ & $\begin{array}{c}\text { Caps } \\
25 \mathrm{~mm} \\
2\end{array}$ \\
\hline & Qt & $\begin{array}{l}\text { Pipe } \\
\text { y Leng } \\
(\mathrm{mm}\end{array}$ & & \\
\hline & 3 & 360 & & \\
\hline & I & 246 & & \\
\hline & 2 & 220 & & \\
\hline & 7 & I 88 & & \\
\hline & 7 & I 74 & & \\
\hline & 2 & I 54 & & \\
\hline & 4 & 140 & & \\
\hline & 2 & I 27 & & \\
\hline & 5 & 119 & & \\
\hline & I 2 & 84 & & \\
\hline & 2 & 66 & & \\
\hline & $2 \mathrm{I}$ & 32 & & \\
\hline
\end{tabular}

depth and tapped with a thread of $3 / 8$ inch in diameter and 26 threads per inch.

The two vertical rods in the front section are pre-drilled and tapped at the bottom end, and inserted into the vertical PVC tubing, to take the pintles of the front castors. The vertical mounts of the back rest are reinforced with continuous fibreglass rowings. When the frame is assembled resin is poured into all the tubing of the frame, giving added strength, rigidty and durability. Once poured the resin requires two hours to set and 24 hours to cure.

\section{The seat}

The seat, back rest and foot plate are made entirely of soft PVC tubing of $8 \mathrm{~mm}$ diameter. The total length of this tubing is 50 metres and it is laced around the chair and held in position with $12 \mathrm{~mm}\left(\frac{1}{2}\right.$ inch) tees.

\section{The wheels}

Two bicycle back wheels of $600 \mathrm{~mm}$ in diameter are used for the large wheels. The threaded axle of each wheel is screwed into either end of the aluminium alloy axle. The outside ends of the wheel axles are covered with a plastic cap for safety reasons.

The front wheels are $175 \mathrm{~mm}$ ( 7 inch) castors which are screwed into the vertical rods within the PVC tubing. Adaptors are available to fit smaller diameter wheels if required. (Appendix I). 


\section{Discussion}

The chair offers many advantages over existing chairs since it is made of readily available materials, which can be purchased in most hardware stores. The assembly and repair can be performed by unskilled labour and can be made available in kit form. The frame will not rust and a cushion is not required. This chair with brakes attached weighs $13 \mathrm{~kg}$. The soft PVC lacing shapes the body and spreads the pressure evenly over the buttocks. In warm climates the spacing between the lacing allows aeration and prevents extensive sweating. The chair can be used as a normal wheelchair as well as a shower or commode chair. The cost of the chair including labour on the axle and rods, amounts to $\$ 100$ Australian. It can be assembled in 2 hours.

This chair has now been in use for 18 months in various conditions, such as temperate areas, the dry, hot and sunny areas of central Australia and the tropical areas found in the South Pacific Islands. Following research with earlier prototypes, the latest wheelchairs have been reinforced with resin and rod inserts. The frame then presents all the advantages of lamination.

In our hospital this chair is used daily to transfer patients in and out of the large hydrotherapy pool. Eighty chairs are now distributed through the various communities from which we receive reports and recommendations.

The concept of using readily available material for a useful aid to the disabled is presented.

This chair is now commercially available from Barrere Surgical Company, 243 Castlereagh Street, Sydney. Further details may be obtained from The Spinal Research Unit, Royal North Shore Hospital of Sydney.

\section{RÉSUMÉ}

Ce nouveau concept de fauteuil roulant offre l'avantage que le fauteuil est entièrement fabriqué de matériaux plastiques disponsibles dans la majorité des quincailleries et il est equipé de roues arrière de bicyclette. Le fauteuil ne requiert point de coussin et ne pèse que $12 \mathrm{~kg}$ avec des roulettes avant de $100 \mathrm{~mm}$ ou $13 \mathrm{~kg}$ avec des roulettes de $175 \mathrm{~mm}$. Le fauteuil est trés maniable.

Le concept sur lequel est basé le dessin de ce fauteuil permet de l'employer comme fauteuil roulant conventionnel aussi bien que comme fauteuil de douche ou tilette. Si nécessaire des resposoirs et des freins peuvent être ajoutés. Les matériaux utilisés sont relativement bon marché et généralement disponibles dans la plupart des pays.

\section{ZUSAMMENFASSUNG}

Dieser Rollstuhl stellt ein neues Konzept dar. Er ist aus Kunstsoff gebaut und ist mid Fahrrad Raedern ausgerustet. Der Stuhl braucht kein Kissen, weigt nur I 2 Kg mit 100 $\mathrm{mm}$ Vorderraedern und $13 \mathrm{Kg}$ mit $175 \mathrm{~mm}$ Raedern. Er laesst sich gut bedienen.

Der Stuhl kann als konventioneller Rollstuhl oder als Dusche/Toilleten Stuhl verwendet werden. Armlehnen und Stosskranze sind erhaltlich. Das Material is billing und steht in fast allen laendern zur verfugung.

\section{REFERENCES}

McFarland, S. R. et al. (1975). 'Fibre reinforced composites for orthotics, prosthetics and mobility aids'. Biomedical Sciences Instrumentation, Vol. II, I 5 I-I 55. 
McFarland, S. R., Laenger, C. J., Francis, P. H. \& Ziperman, H. H. Vol. II p. I5I-I 55 Biomedical Sciences Instrumentation; Fiber Reinforced Composites for Orthotics, Prosthetics and Mobility Aids (1975).

APPENDIX I

\section{Specifications}

Materials:

Frame: $9 \mathrm{~m}$ of $15 \mathrm{~mm}$ PVC pipe Class $\mathrm{I}$, ultraviolet light protected

Glued with solvent cement and $15 \mathrm{~mm}$ fittings

$39 \times$ Tees

$9 \times 90^{\circ}$ elbows

$4 \times 45^{\circ}$ elbows

I $\times$ cap

$2 \times 25 \mathrm{~mm}$ caps

I stainless steel back axle $5 / 8^{\prime \prime}$ for back wheels

2 aluminium alloy rods for front castors

Frame is filled with Epoxy resin

Seat: $\quad 50 \mathrm{~m}$ of $8 \mathrm{~mm}$ soft PVC tubing

Wheels: Rear-standard 24" rear bicycle wheels

Front-standard 4" or 7" castors

$24^{\prime \prime}=600 \mathrm{~mm}$

$4^{\prime \prime}=100 \mathrm{~mm}$

$7^{\prime \prime}=175 \mathrm{~mm}$ 